\title{
ANALISIS PENGARUH PENANAMAN MODAL ASING (PMA), PENANAMAN MODAL DALAM NEGERI (PMDN) DAN EKSPOR TERHADAP PERTUMBUHAN EKONOMI DI PROVINSI JAWA TIMUR TAHUN 2009-2019
}

\section{Avivi Makasmita Meliani*, Sugeng Widodo, Ermatry Hariani}

Program Studi Ekonomi Pembangunan, Fakultas Ekonomi dan Bisnis, Universitas Wijaya Kusuma Surabaya

Corresponding author: avivimakasmita43@gmail.com

\section{Artikel Info \\ Article history: \\ Received 08 June 2021 \\ Revised 18 August 2021 \\ Accepted 30 August 2021 \\ Available online 31 August 2021}

Keyword: foreign investment, domestic investment, exports, economic growth \begin{abstract}
State development is a major development from a certain condition to a situation that is considered more valuable. One of the main requirements for economic growth is the investment criteria, apart from investment, of course, there are many factors that can affect economic growth, namely exports. The research objective to be achieved is to determine the effect of foreign investment, domestic investment, and exports on economic growth. The approach used in this research is quantitative. The variables of this study consist of independent variables, namely PMA, PMDN, and exports in East Java, while the dependent variable is economic growth. Data collection uses secondary data obtained from the Central Statistics Agency of East Java from 2009-2019. The data were analyzed using multiple linear regression analysis through the $F$ test and $T$ test with classical assumptions. The results of the study indicate that partially for PMA,PMDN, and exports have a significant effect on economic growth in East Java, and simultaneously there is a significant influence between PMA, $P M D N$, and exports on economic growth in East Java.
\end{abstract}

\section{PENDAHULUAN}

Pembangunan negara merupakan pembangunan yang menyeluruh dari suatu keadaan tertentu ke keadaan yang dipandang lebih bernilai. Menurut Sukirno (2011) mengatakan pertumbuhan ekonomi mempunyai indikator yang penting dalam melakukan pembangunan ekonomi disebuah negara. Pertumbuhan ekonomi menunjukkan suatu kegiatan perekonomian yang dapat menghasilkan pendapatan masyarakat bertambah dan menghasilkan barang dan jasa terhadap faktor produksi yang dimiliki oleh masyarakat. Dengan adanya kegiatan perekonomian kemakmuran masyarakat akan secara bertahap meningkat.

Dari sisi psikologis, krisis keuangan global serta krisis energi tahun 2008 mempengaruhi sebesar 5,94\% memperambat pertumbuhan ekonomi. Sedangkan tahun 2009 karena dampak krisis masih berlanjut pertumbuhan ekonomi di Jawa Timur hanya tumbuh pada titik 5,01 \% saja. Dengan itu, tahun 2009 penanaman modal asing mengalami penurunan cukup drastis sebesar 35,12

$\%$ jika dibandingkan dengan tahun - tahun sebelumnya. Namun kondisi tersebut berlangsung tidak lama karena pada tahun 2010 penanaman modal asing mengalami peningkatan sebesar 31,49 \% secara perlahan Pada dasarnya investasi dibagi, yaitu investasi yang dilakukan oleh pemerintah atau swasta serta investasi oleh pihak luar negeri. Investasi yang pelakunya 
pemerintah atau swasta lebih dikenal dengan sebutan PMDN atau penanaman modal dalam negeri. Sedangkan, investasi yang pelakunya dari pihak luar negeri dikenal dengan sebutan PMA atau penanaman modal asing. Dengan adanya investasi maka seharusnya akan meningkatkan kapasitas produksi yang kemudian akan meningkatkan output yang dihasilkan. Pentingnya ekspor dalam suatu negara memiliki arti bahwa ekspor memegang peran cukup penting untuk mempengaruhi pertumbuhan ekonomi dan proses pembangunan suatu provinsi. Komponen penting ekspor dari perdagangan luar negeri di Jawa Timur adalah untuk keuntungan yang diperoleh dan peningkatan pendapatan nasional Provinsi Jawa Timur. Dari beberapa pernyataan sebelumnya yang telah dijelaskan, maka dapat disimpulkan judul penelitian ini adalah peengaruh penanaman modal asing, penanaman modal dalam negeri, dan ekspor terhadap pertumbuhan ekonomi. Rumusan masalah nya yaitu : 1) Bagaimana pengaruh penanaman modal asing secara parsial terhadap pertumbuhan ekonomi di Provinsi Jawa Timur tahun 2009-2019? 2) Bagaimana pengaruh penanaman modal dalam negeri secara parsial terhadap pertumbuhan ekonomi di Provinsi Jawa Timur tahun 2009-2019? 3) Bagaimana pengaruh ekspor secara parsial terhadap pertumbuhan ekonomi di Provinsi Jawa Timur tahun 2009-2019? 4) Bagaimana pengaruh penanaman modal asing, penanaman modal dalam negeri, dan ekspor secara simultan terhadap pertumbuhan ekonomi di Provinsi Jawa Timur tahun 2009-2019?

\section{METODE PENELITIAN}

Pendekatan penelitian ini menggunakan pendekatan kuantitatif. Alasan penulis menggunakan penelitian kuantitatif karena data yang diambil berupa angka yang bersumber di website Badan Pusat Statistik. Pengambilan data secara time series untuk menganalisis hipotesis antara penanaman modal asing, penanaman modal dalam negeri, dan ekspor terhadap pertumbuhan ekonomi di provinsi Jawa Timur tahun 2009-2019. Penelitian ini menggunakan alat bantu hitung eviews karena program eviews membantu penulis dalam melakukan uji-uji statistik yang terkait dengan data time series.

\section{Populasi dan Sampel}

Populasi adalah keseluruhan objek pada sebuah wilayah yang akan dilakukan penelitian. Tujuan populasi pada penelitian yakni untuk mendapatkan informasi mengenai data yang ingin diteliti. Populasi yang digunakan dalam penelitian ini adalah Provinsi Jawa Timur. Sampel adalah suatu bagian dari keseluruhan serta karakteristik yang dimiliki oleh sebuah populasi. Sampel yang digunakan dalam penelitian ini adalah data penanaman modal asing, penanaman modal dalam negeri, ekspor dan pertumbuhan ekonomi selama 11 tahun yaitu dari tahun 2009-2019.

Jenis dan Sumber data 
Jenis data yang digunakan pada penelitian ini adalah data kuantitatif. Sumber data yang digunakan adalah data sekunder yang diperoleh dari instansi, lembaga atau sumber-sumber lain yang revelan data. Pada penelitian ini data diperoleh dari website Badan Pusat Statistik Provinsi Jawa Timur. Badan Pusat Statistik Provinsi Jawa Timur meliputi ekspor, laju pertumbuhan ekonomi, penanaman modal asing, dan penanaman modal dalam negeri mulai tahun 2009-2019.

\section{Teknik Analisis Data}

Penelitian ini menggunakan analisis regresi linier berganda digunakan untuk mengukur pengaruh antara lebih dari satu variabel bebas terhadap variabel terikat. Adapun bentuk persamaan regresi linier berganda yang digunakan dalam penelitian ini sebagai berikut:

Keterangan :

$$
Y_{t}=\beta_{0 t}+\beta_{1} X_{1 t}+\beta_{2} X_{2 t}+\beta_{3} X_{3 t}+e_{t}
$$

$\begin{array}{ll}\mathrm{Y}_{\mathrm{t}} & =\text { Pertumbuhan Ekonomi di Jawa Timur } \\ \beta_{0 \mathrm{t}} & =\text { Koefisien Konstanta } \\ \beta_{1,} \beta_{2}, \beta_{3} & =\text { Koefisien regresi } \\ \mathrm{X}_{1 \mathrm{t}} & =\text { Penanaman modal asing } \\ \mathrm{X}_{2 \mathrm{t}} & =\text { Penanaman modal dalam negeri } \\ \mathrm{X}_{3 \mathrm{t}} & =\text { Ekspor } \\ \mathrm{t} & =\text { Time Series } \\ \mathrm{e}_{\mathrm{t}} & \end{array}$

\section{HASIL DAN PEMBAHASAN}

Tabel 1. Hasil Analisis Deskripsi Data

\begin{tabular}{ccccc}
\hline Keterangan & $\begin{array}{l}\text { Pertumbuh } \\
\text { an ekonomi }\end{array}$ & PMA & PMDN & Ekspor \\
\hline Mean & 5,832955 & 59.000 .000 .000 & 35912646 & 182.000 .000 .000 .000 \\
Median & 5,672500 & 46.800 .000 .000 & 36762755 & 167.000 .000 .000 .000 \\
Maximum & 6,640000 & 109.000 .000 .000 & 46310912 & 293.000 .000 .000 .000 \\
Minimum & 5,080000 & 13.800 .000 .000 & 19912810 & 194.000 .000 .000 .000 \\
Std. Dev & 0,425216 & 36.200 .000 .000 & 6317382 & 728.000 .000 .000 .000 \\
\hline
\end{tabular}

Sumber : Data diolah, 2021

Hasil Uji Multikolinearitas Dengan Metode Newey-Wes

Tabel 2. Hasil Uji Multikolinearitas dengan Metode Newey-West

\begin{tabular}{cc}
\hline Variabel & Centered VIF \\
\hline PMA & 1,002903 \\
PMDN & 1,0517302 \\
Ekspor & 1,054858 \\
\hline
\end{tabular}

Sumber : Data diolah, 2021 
Berdasarkan tabel diatas dapat dijelaskan bahwa semua variabel bebas yang meliputi penanaman modal asing, penanaman modal dalam negeri dan ekspor menunjukkan nilai VIF lebih kecil dari 10. maka kesimpulan yang dapat dijelaskan dari hasil uji multikolinearitas pada semua variabel bebas berarti tidak terdapat kasus multikolinearitas.

Hasil Uji Linearitas dengan Metode Newey-West

Tabel 3. Hasil Uji Linearitas dengan Metode Newey-West

\begin{tabular}{cccc}
\hline Criteria & Value & Df & Probability \\
\hline t-statistic & 0,963410 & 39 & 0,3413 \\
f-statistic & 0,928159 & $(1,39)$ & 0,3413 \\
\hline
\end{tabular}

Sumber : Data diolah, 2021

Berdasarkan tabel diatas menunjukan bahwa pada uji ramsey RESET test nilai probability $\mathrm{f}$ - statistic sebesar $0,3413>$ dari nilai probabilitas $\alpha=0,1$. maka hasilnya model ini tidak terdapat masalah linearitas.

Hasil Uji Autokorelasi dengan Metode Newey-West

Tabel 4. Hasil Uji Autokorelasi dengan Metode Newey-West Obs*R-squared Prob.Chi-square(2)

\begin{tabular}{rr}
\hline 38,32156 & 0,0000 \\
\hline
\end{tabular}

Sumber : Data diolah, 2021

Berdasarkan tabel diatas menunjukan bahwa pada uji breusch-godfrey serial correlation LM test nilai Prob.Chi-square sebesar $0,0000<$ dari nilai probabilitas $\alpha=0,1$. maka hasilnya model ini terdapat permasalahan autokorelasi. Bahwa dengan metode newey-west walaupun masih terdapat masalah autokorelasi namun dianggap tidak terdapat masalah.

Hasil Uji Heteroskedastisitas dengan Metode Newey-West

Tabel 5. Hasil Uji Heteroskedastisitas dengan Metode Newey-West

\begin{tabular}{cc}
\hline Obs*R-squared $^{*}$ & Prob.Chi-square(3) \\
\hline 18,08193 & 0,0342 \\
\hline
\end{tabular}

Sumber : Data diolah, 2021

Berdasarkan tabel diatas menunjukkan bahwa pada uji white test. Nilai Obs*R-squared sebesar 18,08193 > dari nilai Prob. Chi-square(3) sebesar 0,0342 dan nilai Prob.Chi-square sebesar $0,0342<$ dari nilai probabilitas $\alpha=$ 0,1 . Maka hasilnya model ini terdapat permasalahan heteroskedastisitas. Bahwa dengan metode newey-west walaupun masih terdapat masalah heteroskedastisitas namun dianggap tidak ada masalah heteroskedastisitas. 
Hasil Uji Normalitas dengan Metode Newey-West

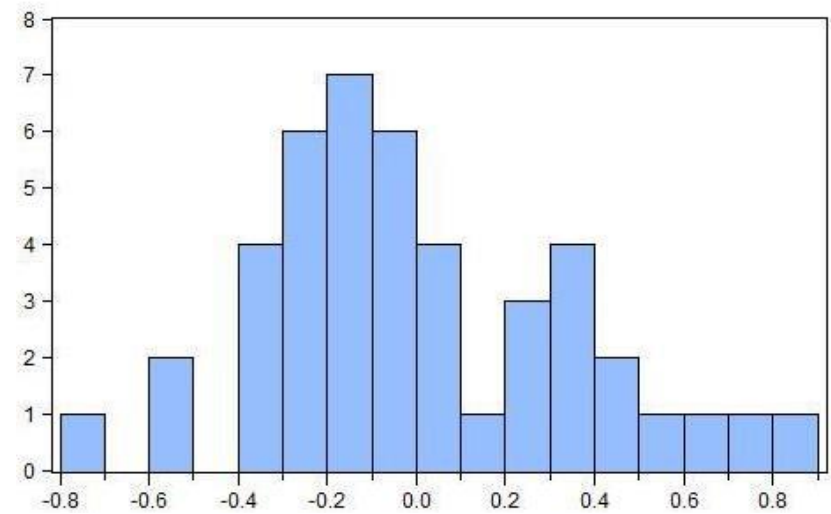

$$
\begin{array}{|lc|}
\hline \multicolumn{2}{|l|}{\text { Series: Residuals }} \\
\text { Sample 2009Q1 2019Q4 } \\
\text { Observations } 44 \\
\text { Mean } & -1.94 \mathrm{e}-16 \\
\text { Median } & -0.045880 \\
\text { Maximum } & 0.864843 \\
\text { Minimum } & -0.788983 \\
\text { Std. Dev. } & 0.352947 \\
\text { Skewness } & 0.387142 \\
\text { Kurtosis } & 2.939395 \\
& \\
\text { Jarque-Bera } & 1.105847 \\
\text { Probability } & 0.575266 \\
\hline
\end{array}
$$

Sumber : Data diolah, 2021

Gambar 1. Uji Normalitas dengan Metode Newey-West

Berdasarkan gambar diatas menunjukkan bahwa uji Jarque-berra test. Nilai Jarque-berra sebesar $1,105847>$ dari nilai Probability sebesar 0,575266 dan Nilai Probability sebesar 0,575266 > dari nilai probabilitas $\alpha$ $=0,1$. Maka hasilnya model ini berdistribusi normal.

Hasil Analisis Regresi Linear Berganda dengan Metode Newey-West

Tabel 6. Hasil Analisis Regresi Linear Berganda dengan Metode NeweyWest

\begin{tabular}{lll}
\hline Variabel & Koefisien & Probabilitas \\
\hline C & 5,346771 & 0,0000 \\
Penanaman Modal Asing & $-0,00000000000350$ & 0,0807 \\
Penanaman Modal Dalam & 34.700 .000 .000 & 0,0270 \\
Negeri & & \\
Ekspor & $-0,00000000000000303$ & 0,0037 \\
\hline
\end{tabular}

Sumber : Data diolah, 2021

Berdasarkan hasil perhitungan tersebut diatas, diperoleh persamaan regresi linear berganda sebagai berikut :

$\mathrm{Y}=5,346771-0,00000000000350 \mathrm{X}_{1}+34.700 .000 .000 \mathrm{X} 2-$

$0,00000000000000303 \mathrm{X}_{3}+\mathrm{e}_{\mathrm{t}}$

Interprestasi dari model regresi diatas sebagai berikut:

1. Nilai konstan sebesar 5,346771 yang menunjukkan bahwa pada saat variabel penanaman modal asing, penanaman modal dalam negeri, dan ekspor dianggap konstan maka nilai variabel pertumbuhan ekonomi sebesar 5,346771.

2. Nilai koefisien penanaman modal asing menunjukan senilai 0,00000000000350 yang artinya menunjukkan bahwa variabel penanaman modal asing berpengaruh negatif maksud dari negatif ialah - jika penanaman modal asing ditingkatkan, maka akan mengakibatkan 
penurunan Pertumbuhan Ekonomi senilai -0,00000000000350.

3. Nilai koefisien penanaman modal dalam negeri menunjukan senilai 34.700.000.000 yanga artinya menunjukan bahwa variabel penanaman modal dalam negeri berpengaruh positif maksud dari positif ialah jika penanaman modal dalam negeri ditingkatkan, maka akan mengakibatkan peningkatan pada pertumbuhan ekonomi senilai 34.700.000.000.

4. Nilai koefisien ekspor menunjukan senilai $-0,00000000000000303$ yang artinya menunjukkan bahwa variabel ekspor berpengaruh negatif maksud dari negatif ialah jika ekspor ditingkatkan maka akan mengakibatkan penurunan Pertumbuhan Ekonomi senilai -0,00000000000000303.

Analisis Koefisien Determinasi dengan Metode Newey-West

Tabel 7. Koefisien Determinasi dengan Metode Newey-West R-squared Adjusted R-squared $0,311028 \quad 0,259356$

Sumber : Data diolah, 2021

Dari hasil koefisien determinasi pada tabel diatas dapat nilai sebesar 0,311028 dapat diambil kesimpulan bahwa besarnya pengaruh variabel bebas penanaman modal asing, penanaman modal dalam negeri, dan ekspor dengan variabel terikat pertumbuhan ekonomi sebesar $31,10 \%$, sedangkan $68,9 \%$ sisanya dipengaruhi oleh faktor lain diluar penelitian.

Uji Parsial (Uji T) dengan Metode Newey-West

Tabel 8. Hasil Analisis Uji T dengan Metode Newey-West

\begin{tabular}{llll}
\hline Variabel & Koefisien & t-statistik & Probabilitas \\
\hline PMDN & 34.700 .000 .000 & 2,295474 & 0,0270 \\
Ekspor & $-0,00000000000000303$ & $-3,085125$ & 0,0037 \\
\hline
\end{tabular}

Sumber : Data diolah, 2021

Berdasarkan dari tabel diatas didapatkan hasil pengujian sebagai berikut :

1. Uji parsial antara variabel penanaman modal asing terhadap pertumbuhan ekonomi. Hasilnya menunjukkan bahwa variabel penanaman modal asing memiliki nilai probabilitas sebesar 0,0807 yang lebih kecil dari $\alpha$ sebesar $10 \%(0,1)$ maka $\mathrm{H}_{0}$ ditolak sehingga kesimpulannya secara parsial variabel penanaman modal asing berpengaruh signifikan terhadap pertumbuhan ekonomi Provinsi Jawa Timur.

2. Uji parsial antara penanaman modal dalam negeri terhadap pertumbuhan ekonomi. Hasilnya menunjukkan bahwa variabel penanaman modal dalam negeri memiliki nilai probabilitas sebesar 
0,0270 yang lebih kecil dari $\alpha$ sebesar $10 \%(0,1)$ maka $H_{o}$ ditolak sehingga kesimpulannya secara parsial variabel penanaman modal dalam negeri berpengaruh signifikan terhadap pertumbuhan ekonomi Provinsi Jawa Timur.

3. Uji parsial antara ekspor terhadap pertumbuhan ekonomi. Hasilnya menunjukkan bahwa variabel ekspor memiliki nilai probabilitas sebesar 0,0037 yang lebih kecil dari $\alpha$ sebesar $10 \%(0,1)$ maka $\mathrm{H}_{\mathrm{o}}$ ditolak sehingga kesimpulannya secara parsial variabel ekspor berpengaruh signifikan terhadap pertumbuhan ekonomi Provinsi Jawa Timur.

\section{Uji Simultan (Uji F) dengan Newey-West}

Tabel 9. Hasil Analisis Uji F Dengan Metode Newey-West Prob (F-statistik) Prob (wald F-statistik)

$0,001749 \quad 0,003508$

Sumber : Data diolah, 2021

Didapatkan dari hasil uji $\mathrm{F}$ diatas maka dapat diketahui, nilai probabilitas F-statistik sebesar 0,003508 lebih kecil dari $\alpha$ yaitu $10 \%(0,1)$ maka Ho ditolak sehingga kesimpulannya bahwa seluruh variabel bebas yaitu penanaman modal asing, penanaman modal dalam negeri, dan ekspor berpengaruh secara signifikan terhadap pertumbuhan ekonomi Provinsi Jawa Timur.

Berdasarkan hasil analisis itu ada 2 asumsi klasik yang tidak terpenuhi menggunakan metode newey-west masih terkena masalah autokorelasi dan heteroskedastisitas maka dianggap penelitian autokorelasi dan heteroskedastisitas tersebut tidak terkena masalah atau dianggap bias karena sudah melewati metode newey-west sejalan dengan teori Agus Widarjono (2015) bahwa masih terdapatnya masalah autokorelasi dan heteroskedastisitas masih bisa melakukan evaluasi uji $t$ maupun uji $f$ meskipun masih ada masalah uji autokorelasi dan heteroskedastisitas.

\section{Pengaruh Penanaman Modal Asing Terhadap Pertumbuhan Ekonomi}

Penanaman modal asing akan membuat Provinsi Jawa Timur sebagai penerima modal akan mengalami peningkatan perekonomian di Provinsi Jawa Timur. Dengan adanya penanam modal asing di Provinsi Jawa Timur akan membawa dampak yang positif yakni menaikkan pendapatan per kapita masyarakat dan menurunkan pendapatan. Pada hasil analisis ini pertumbuhan ekonomi di Jawa Timur masih sangat tergantung dari besarnya penanaman modal asing yang masuk ke Provinsi Jawa Timur, karena dengan semakin tinggi penanaman modal asing yang masuk ke Provinsi Jawa Timur akan semakin tinggi pertumbuhan ekonomi di Jawa Timur dan sebaliknya. 
Hasil penelitian ini tidak sesuai dengan penelitian terdahulu yang dilakukan oleh Hapsari dan Prakoso (2016) dengan mengambil kasus pengaruh penanaman modal dan pertumbuhan ekonomi tingkat provinsi di Indonesia. Menyatakan bahwa tidak terdapat pengaruh dan tidak signifikan terhadap pertumbuhan ekonomi. Semakin tinggi penanaman modal asing maka pertumbuhan ekonomi mengalami penurunan.

Signifikannya penanaman modal asing dengan pertumbuhan ekonomi di Jawa Timur dapat dilihat pada tahun 2010 nilai penanaman modal asing sebesar 31,49 persen dan pertumbuhan ekonomi pada tahun 2009 sebesar 5,08 persen menjadi 6,31 persen pada tahun 2010. Hal ini menunjukkan bahwa penanaman modal asing yang tinggi maka mempengaruhi pertumbuhan ekonomi. Semakin tinggi penanaman modal asing di Jawa Timur adanya kepercayaan pihak swasta yang ikut meningkatkan pertumbuhan ekonomi di Jawa Timur.

\section{Pengaruh Penanaman Modal dalam Negeri Terhadap Pertumbuhan Ekonomi}

Penanaman modal dalam negeri ini telah dipandang sebagai faktor pendorong di dalam pembangunan ekonomi. Dengan adanya penanaman modal dalam negeri akan menciptakan

pendapatan dan memperbesar kapasitas produksi. Pada hasil penelitian ini variabel penanaman modal dalam negeri berpengaruh terhadap pertumbuhan ekonomi di Provinsi Jawa Timur, karena dengan semakin tinggi penanaman modal di Jawa Timur maka akan semakin tinggi pertumbuhan ekonomi di Jawa Timur dan sebaliknya.

Hasil penelitian ini sesuai dengan penelitian terdahulu yang dilakukan oleh Muazi dan Arianti (2013) dengan mengambil kasus pengaruh penanaman modal asing, penanaman modal dalam negeri terhadap pertumbuhan ekonomi. Menyatakan bahwa penanaman modal dalam negeri di Jawa Tengah pada jangka pendek dan jangka panjang berpengaruh secara positif dan signifikan terhadap pertumbuhan ekonomi Jawa Tengah. Walaupun penanaman modal dalam negeri berfluktuasi, tetapi dapat diandalkan untuk peningkatan PDRB Jawa Tengah.

Signifikannya penanaman modal dalam negeri dengan pertumbuhan ekonomi di Jawa Timur dapat dilihat pada tahun 2012 nilai penanaman modal dalam negeri sebesar 90,31 persen dan pertumbuhan ekonomi pada tahun 2011 sebesar 6,44 persen menjadi 6,64 persen pada tahun 2012. Hal ini menunjukan bahwa penanaman modal dalam negeri tinggi maka pertumbuhan ekonomi Jawa Timur juga ikut meningkat. Meningkatnya penanaman modal dalam negeri di Jawa Timur tidak hanya pihak swasta yang berupaya dalam melakukan penanaman modal dalam negeri tetapi pemerintah juga ikut berperan.

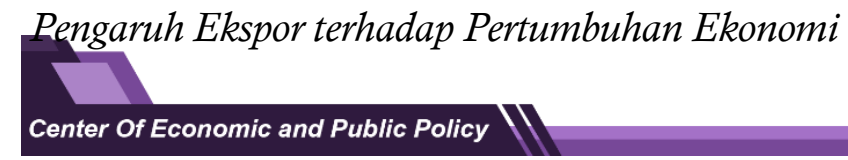


Ekspor bisa terjadi jika sudah cukupnya kebutuhan akan barangbarang tertentu di dalam negeri ataupun baik produk dalam kualitas atau harga dengan produk yang satu jenis di dalam pasar perdagangan internasional. Ekspor akan memberikan peningkatan terhadap pertumbuhan ekonomi dan pendapatan provinsi. Pada hasil penelitian ini variabel ekspor berpengaruh terhadap pertumbuhan ekonomi di Provinsi Jawa Timur. Artinya dalam penelitian ini meningkatnya ekspor suatu perusahaan di Provinsi Jawa Timur dapat menjadi tolak ukur dalam meningkatnya pertumbuhan ekonomi di Provinsi Jawa Timur dan sebaliknya.

Hasil penelitian ini sesuai dengan penelitian terdahulu yang dilakukan oleh Astuti dan Ayuningtyas (2018) dengan mengambil kasus pengaruh ekspor dan impor terhadap pertumbuhan ekonomi di Indonesia. Menyatakan bahwa dalam jangka panjang dan jangka pendek ekspor berpengaruh signifikan terhadap pertumbuhan ekonomi di Indonesia. Ekspor yang meningkat akan mendorong peningkatan produksi dalam negeri.

Signifikannya ekspor dengan pertumbuhan ekonomi di Jawa Timur dapat di lihat dari tahun 2018 nilai ekspor sebesar 19,24 persen dan pertumbuhan ekonomi pada tahun 2017 sebesar 5,46 persen menjadi 5,50 persen pada tahun 2018. Hal ini menunjukan bahwa ekspor mengalami peningkatan maka pertumbuhan ekonomi di Jawa Timur mengalami peningkatan. Peningkatan ekspor Jawa Timur dapat meningkatkan pendapatan provinsi dan menjaga stabilitas neraca perdagangan provinsi.

\section{KESIMPULAN}

Berdasarkan dari pembahasan diatas maka dapat disimpulkan bahwa penanaman modal asing secara parsial berpengaruh signifikan terhadap pertumbuhan ekonomi di Provinsi Jawa Timur. Penanaman modal dalam negeri secara parsial berpengaruh signifikan terhadap pertumbuhan ekonomi di Provinsi Jawa Timur. Ekspor secara parsial berpengaruh signifikan terhadap pertumbuhan ekonomi di Provinsi Jawa Timur. Penanaman modal asing, penanaman modal dalam negeri, dan ekspor secara simultan berpengaruh signifikan terhadap pertumbuhan ekonomi di Provinsi Jawa Timur.

Dari hasil penelitian ini tentang penanaman modal asing, penanaman modal dalam negeri, dan ekspor terhadap pertumbuhan ekonomi di Provinsi Jawa Timur tahun 2009-2019. Maka dapat diperoleh sebagai berikut: diketahui penanaman modal asing, penanaman modal dalam negeri, dan ekspor secara bersama-sama berpengaruh terhadap pertumbuhan ekonomi di Provinsi Jawa Timur, oleh karena itu dalam usaha untuk meningkatkan pertumbuhan ekonomi maka cara yang dapat dilakukan adalah melalui pemantauan penanaman modal asing, penanaman modal dalam negeri, dan ekspor secara tepat dan berkala. Peneliti lain yang tertarik dengan topik yang sama, disarankan untuk mengambil periode tahun yang lain, menentukan objek 
penelitian diluar Jawa Timur dan juga menambahkan variabel lain yang mampu berdampak pada pertumbuhan ekonomi.

\section{DAFTAR PUSTAKA}

Astuti, I. P., dan F. J. Ayuningtyas.(2018). "Pengaruh Ekspor Dan Impor Terhadap Pertumbuhan Ekonomi Di Indonesia".Jurnal Ekonomi dan Studi Pembangunan. 19 (1) : 1-10.

Badan Pusat Statistik Provinsi Jawa Timur.(2021). Data Laju Pertumbuhan Ekonomi 2009-2019.

Diakses Januari 29, 2021 dari : https://jatim.bps.go.id/

Badan Pusat Statistik Provinsi Jawa Timur.(2019). Data Ekspor 2009-2019.

Diakses Desember 4, 2019 dari : https://jatim.bps.go.id/

Badan Pusat Statistik Provinsi Jawa Timur.(2020). Data Penanaman Modal Asing 2009-2019.

Diakses Desember 4, 2020 dari : https://jatim.bps.go.id/

Badan Pusat Statistik Provinsi Jawa Timur.(2020). Data Penanaman Modal Dalam Negeri 2009- 2019. Diakses Desember 4, 2020 dari : https://jatim.bps.go.id/

Hapsari, R. D., dan I. Prakoso. (2016). "Penanaman Modal dan Pertumbuhan Ekonomi Tingkat Provinsi di Indonesia".Jurnal Ekonomi dan Bisnis. 19 (2) : 211-224.

Jhingan, M.L. (2007). “Ekonomi Pembangunan dan Perencanaan”. Jakarta : PT. Raja Grafindo Persada.

Muazi, N. M., \& Arianti, F. (2013). "Analisis Pengaruh Penanaman Modal Asing dan Penanaman Modal Dalam Negeri Terhadap Pertumbuhan Ekonomi : di Jawa Tengah 1990 - 2010". Diponegoro Journal of Economics, $2(1), 1-9$.

Samuelson, P.A dan Nordhaus, W.D. (1994). "Makro Ekonomi". http://repository.usu.ac.id/bitstream/handle/123456789/44748/c hapter\%20II.pdf.sequence=4 (Diakses 04 Desember 2020).

Sukirno, S. (2011).Makro Ekonomi Teori Pengantar Edisi Ketiga. Rajawali. Pers, Jakarta.

Undang-undang Republik Indonesia Nomor 25 tahun 2007 tentang Penanaman

Modal.https://jdih.kemenkeu.go.id/FullText/2007/25TAHUN200 7uu.htm. (Diakses 04 Desember 2020)

Widarjono, A. (2018). Ekonometrika Pengantar dan Aplikasi eviews. Yogyakarta : penerbit UPP STIM YKPN. 